\title{
TITRATION OF THE SHOPE FIBROMA VIRUS IN VITRO
}

\author{
J. JEŘ́AEK, L. DEDEK \\ Department of Prophylaxis of Pig Diseases, Animal Breeding and Zoohygiene, University of \\ Veterinary Science, 61242 Brno, and Bioveta, 68323 Ivanovice na Hané
}

Received May 18, 1979

\begin{abstract}
Jeřábek J., L. Dedek: Titration of the Shope Fibroma Virus in vitro. Acta vet. Brno, 50, 1981: 89-96.

For titration of the Shope fibroma virus propagated in cell line RK 13 besides rabbits also the cell culture line RK 13 may be used. Titration in vitro by both the test tube method and micromethod in plates can replace the laborious titration in rabbits employed up to now. The micromethod proved to be more advantageous as it is simple and time-saving. Titration in vitro may be used to test any phase of vaccine production, a fact important not only for vaccine standardization but also for production economy.
\end{abstract}

Myxomatosis, vaccination, comparison, test tube method, micromethod.

Determination of the virus titer belongs to the test methods testing the vaccine against rabbit myxomatosis. The vaccine made in CSSR from the Shope fibroma virus (SFV) replicated in rabbits has been up to now titrated in these animals (Mádr et al. 1967; Cu upera 1969; Mádr 1971). Along with the advantage of testing the vaccination virus in animal species for which the vaccine is produced there is a disadvantage of using mostly the final product for titration. In case of unsatisfactory results obtained from titration the vaccine may not be used. Thus production efficacy is decreased. Moreover, virus titration in rabbits is laborious and may yield no standard results.

Data on successful SFV replication in cells isolated from rabbits with virus propagation being. accompanied by characteristic changes of the cell substrate employed (Padgett et al. 1962; Verna and Eylar 1962; Hinze and Walker 1964, 1971; Woodroofe and Fenner 1965; Jacquemont et al. 1972; Kasza 1974; Zerbini et al. 1975; Crouch 1978) have led us to study the SFV titration in vitro. The aim of the experiment was to propose a simple SFV titration in vitro procedure easy to use in each phase of vaccine production including control of the final product-lyophilized vaccine against rabbit my xomatosis SFT (Shope fibroma virus propagated in tissue culture).

\section{Materials and Methods}

For titration 18 samples were used containing SFV propagated in rabbit kidney cell line RK 13. Various virus passages (samples No. $2,6,9,13,16,17$ ) were verified, as well as vaccines prepared from this virus before lyophilization (samples No. 8, 10, 11, 18), lyophilized vaccines SFT (samples No. $1,5,7,15,19$ ), lyophilized vaccines stored at $+4{ }^{\circ} \mathrm{C}$ (samples No. 3 and 12), and lyophilized vaccine stored at room temperature (sample No. 4). Lyophilized vaccine prepared from SFV replicated in rabbits was titrated, too (sample No. 14).

For titration in vitro both test tube and micromethod were used. Results of virus titration in vitro were compared with those obtained in rabbits. As various volumes of virus were used $\left(1 \mathrm{~cm}^{3}\right.$, $0.05 \mathrm{~cm}^{3}$ and $0.25 \mathrm{~cm}^{3}$ ), for comparison of the titration results after determination of the virus titer by the method of Reed and Muench (1938) the virus amount per $1 \mathrm{~cm}^{3}$ volume was calculated.

Test-tube method

Titration indicates the viral dilution at which cytopathic effect occurs manifested by destruction of cell monolayer or hyperplasia of the infected cells (Fig. 1, 2, 3). 


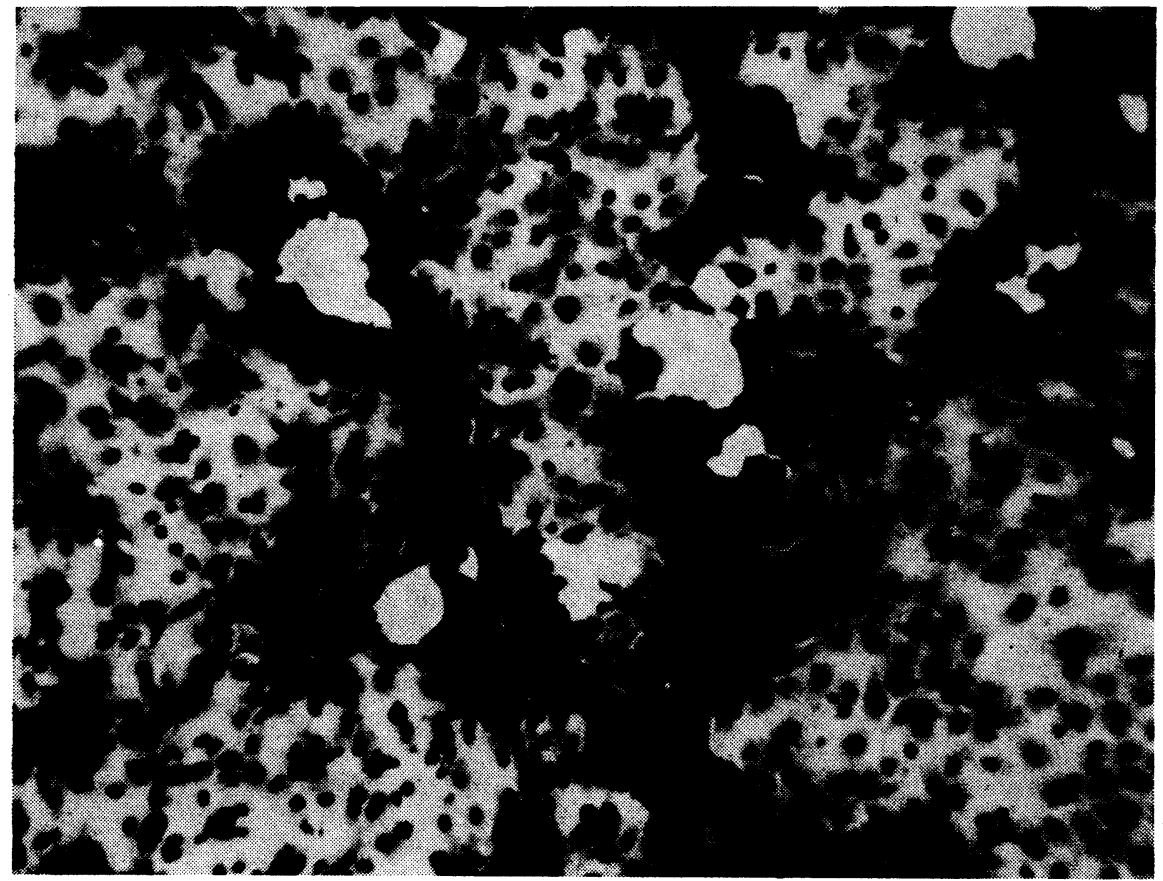

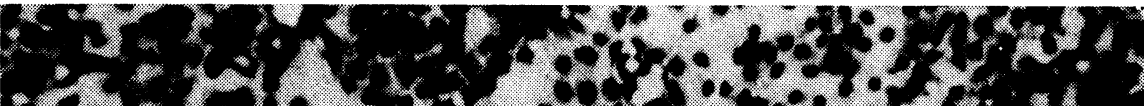

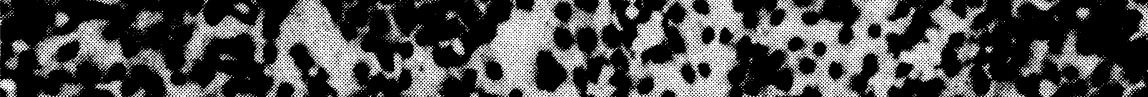

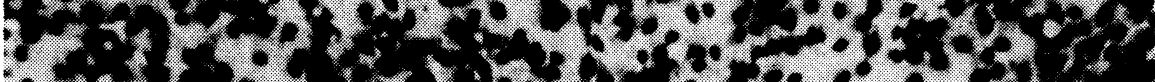

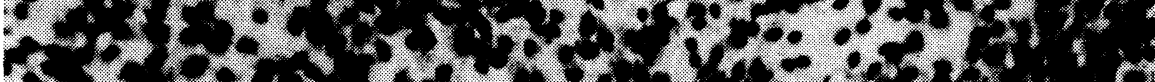
(3)

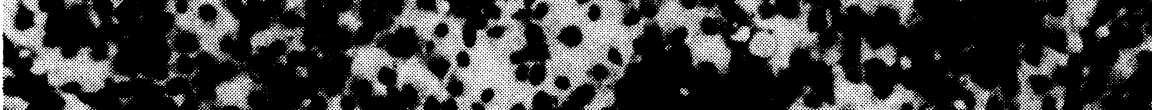

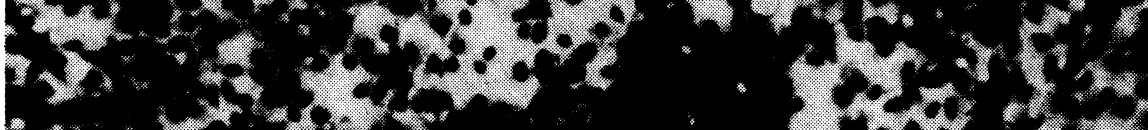

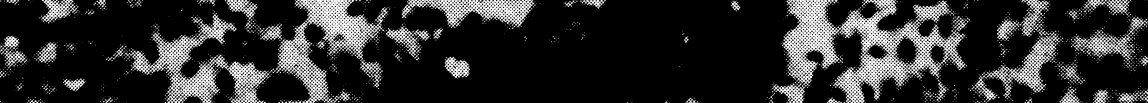

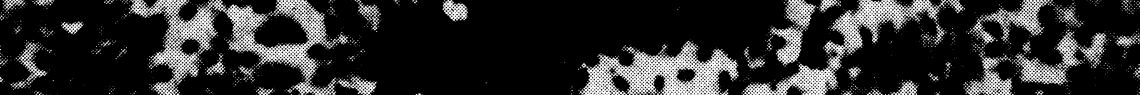

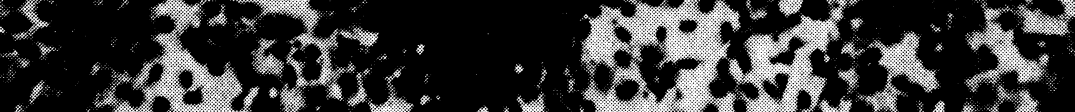

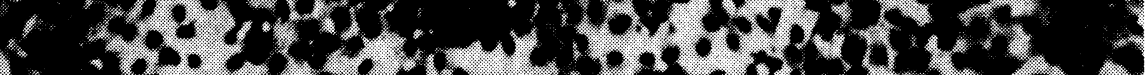

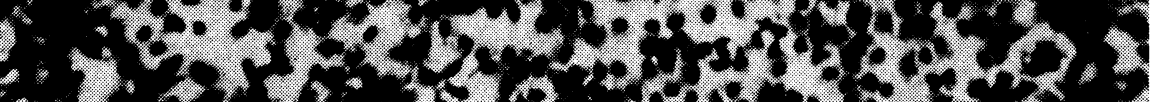

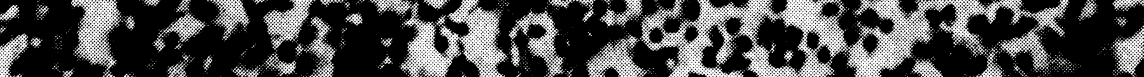

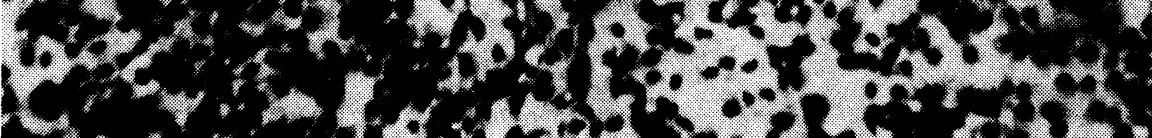

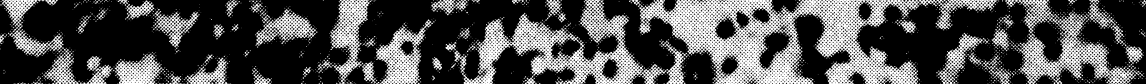




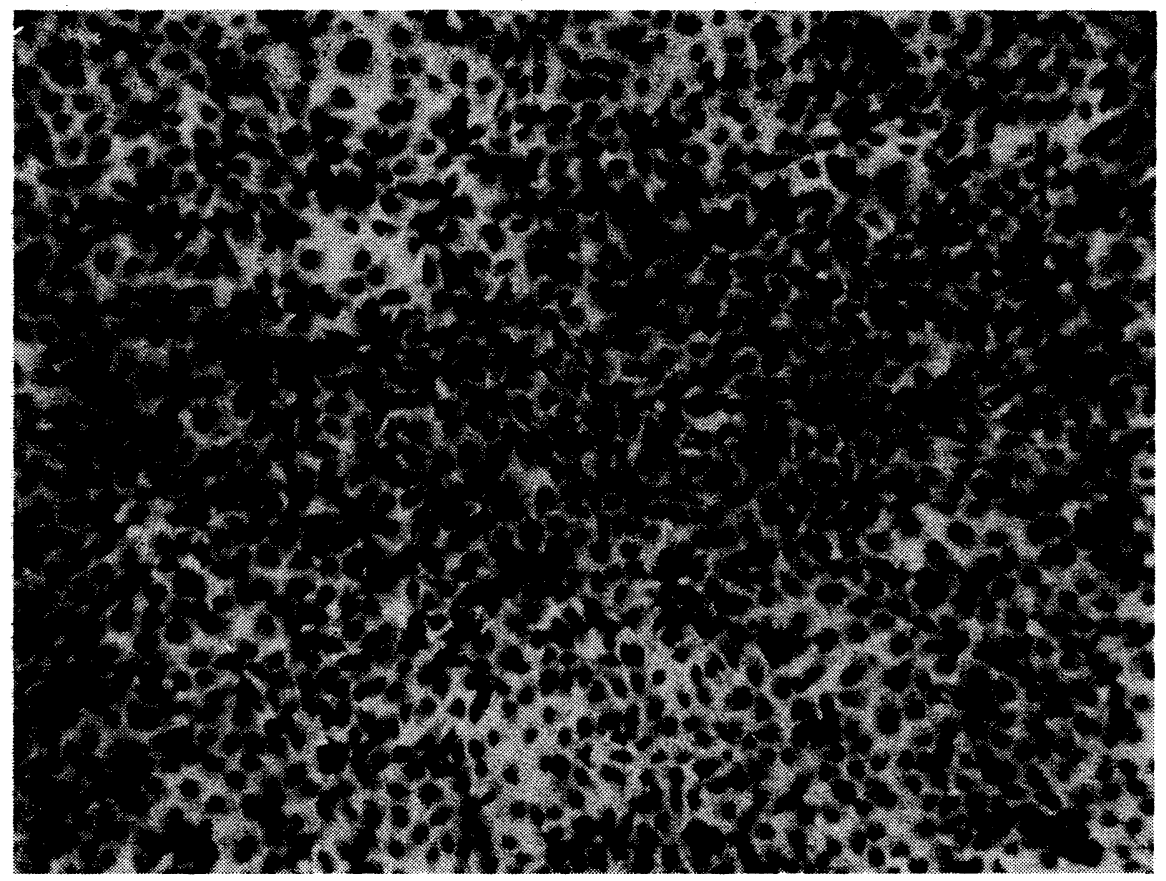

Fig. 3

Test tube method. Control non-infected monolayer of the cell line RK 13. x 103 .

\section{Procedure}

For virus titration test tubes with 3-to 5-day old monolayer of RK 13 line cells propagated in the growth medium MEM (Eagle) were employed.

In the maintenance medium MEM (without serum) the diluted volume of the tested virus was prepared $\left(10^{-1}\right.$ to $\left.10^{-5} / 1 \mathrm{~cm}^{3}\right)$. From each dilution the virus-containing medium, amounting $1 \mathrm{~cm}^{3}$, was inoculated into at least 4 test tubes with cell monolayer. The tubes were incubated at $36-37^{\circ} \mathrm{C}$.

For viral titer determination in lyophilized vaccine it is necessary to prepare the basic dilution using water for tissue cultures, corresponding to the amount of undiluted viral suspension before lyophilization (e. g. with lyophilized $4 \mathrm{~cm}^{3}$ of harvester virus $+2 \mathrm{~cm}^{3}$ of lyophilic medium the basic dilution is prepared by addition of $4 \mathrm{~cm}^{3}$ water).

\section{Evaluation of the test}

The final evaluation was done on day 5 after inoculation of the monolayers. The dilution was determined at which changes in cell culture had appeared. CPE consists of destruction of cell culture (at lower dilution) and/or focal hyperplasia of cell monolayer (especially at higher dilutions). For determination of the final titer both changes are of equal value.

\section{Fig. 1}

Test tube method. Vaccine dilution $10^{-1}$. Characteristic hyperplasia of cell monolayer and its partial destruction. $\mathbf{x} 103$.

Fig. 2

Test tube method. Vaccine dilution $10^{-4}$. Two characteristic confluent hyperplastic foci in the monolayer. x 103. 


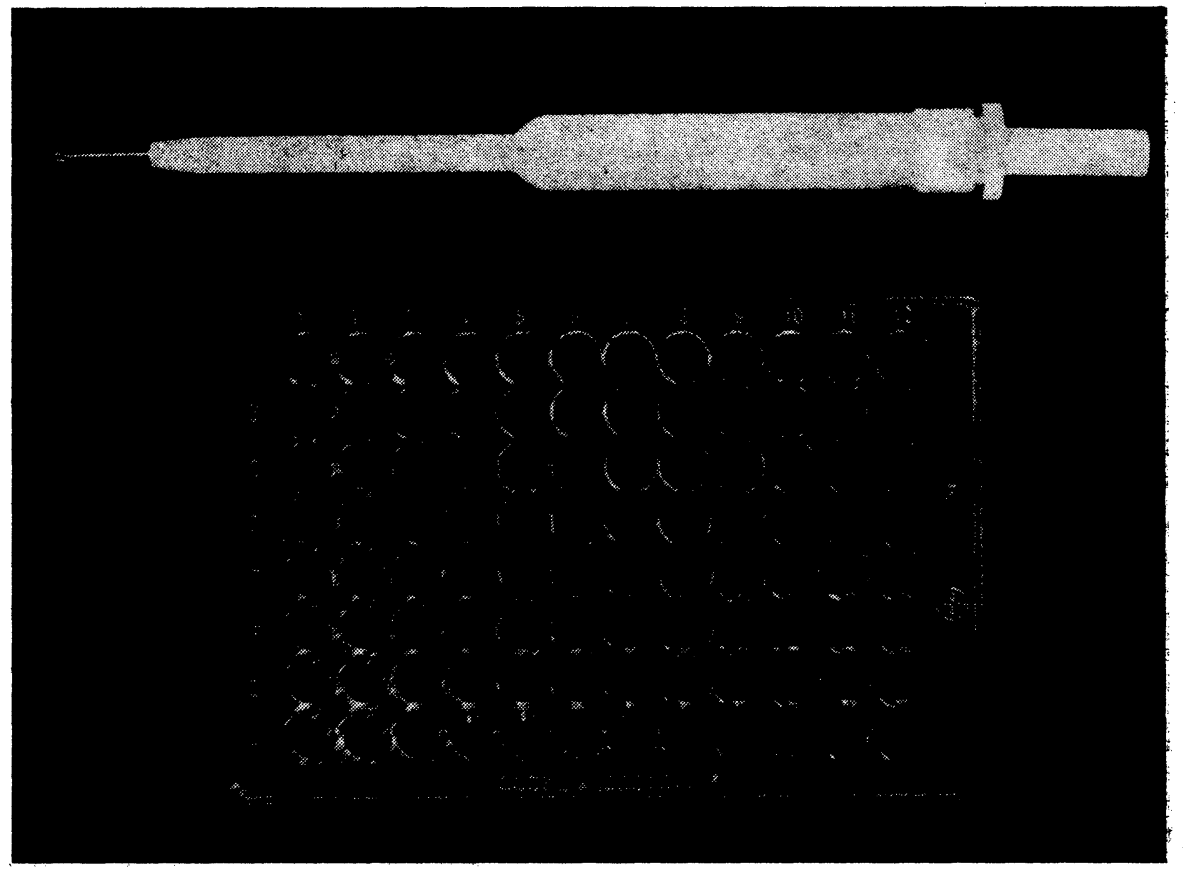

Fig. 4

Plate and micropipette employed in the experiments (Dynatech).

Evaluation of changes with the test tube method and micromethod does not differ:

+++ massive cytopathic effect (destruction of monolayer)

++ numerous hyperplastic foci

$+\quad$ solitary hyperplastic foci

- no changes in monolayer.

For final evaluation all positive reactions were considered $(+$ to +++ ).

\section{Micromethod}

This test also serves to determine the viral dilution at which CPE consisting of monolayer destruction or hyperplasia of the infected cells occurs (Fig. 5 and 6). For titration, sterile plates and pipettes were used with drop magnitude of $0.05 \mathrm{~cm}^{3}$. In the present experiment plates and micropipettes of the Dynatech Company were used (plate No. M-29ARTL and pipettes No. M-17, see Fig. 4).

\section{Procedure}

Cell suspension in growth medium (MEM $+10 \%$ serum) was prepared (density of 400000 to 600000 cells per $1 \mathrm{~cm}^{3}$ ). The tested virus was diluted in the growth medium MEM. Each well of the plate was filled with one drop $\left(0.05 \mathrm{~cm}^{3}\right)$ of the growth medium. Invariably 4 wells were filled with one drop of undiluted virus and virus diluted at $10^{-1}$ to $10^{-5}$. Into each well one drop of cell suspension was added. The control wells contained 1 drop of cell suspension and 2 drops of growth medium. The covered plate was incubated at 36 to $37^{\circ} \mathrm{C}$ and maximum $5 \% \mathrm{CO}_{2}$ concentration in an humidified atmosphere.

\section{Evaluation of the test}

The final dilution at which changes had occurred was determined under inversion microscope on day 5 . The same changes as with the test tube method were determined. With this method, too, cell hyperplasia is massive so that for $(+)$ one hyperplastic focus in the infected monolayer is sufficient. After the viral titer determination in $0.05 \mathrm{~cm}^{3}$ it is necessary to add $1.3 \mathrm{log}$ to obtain the final result in $1 \mathrm{~cm}^{3}$. 
Titration in rabbits

was simultaneously done with 2 animals employing the method currently used in Czechoslovakia (J eřábek 1980).

The virus titer was calculated in $0.25 \mathrm{~cm}^{3}$ and for the final results to be expressed per $1 \mathrm{~cm}^{3}$ $0.6 \log$ was added.

\section{Results and Discussion}

Propagation of the Shope fibroma virus in cells of the RK 13 line is connected with occurrence of specific changes in these cells. The fact that cell destruction after the application of larger amounts of virus occurs (Fig. 1 and 5), and hyperplasia of the infected cells (Fig. 2 and 6) after inoculation of smaller amount of virus (Jacquemont et al. 1972) is observed may be successfully used for SFV titration in vitro. After inoculation of higher viral dilutions characteristic focuses in the infected monolayer occur designated as focus-forming units (FFU) (Crouch 1978). Both cell hyperplasia and destruction can easily be detected and evaluated microscopically.

Table 1 shows that for titration of the Shope fibroma RK 13 cell line-propagated virus and for titration of the vaccine prepared from this virus both the test tube method and micromethod may be employed. However, the micromethod seems to be more advantageous as it is simple and time saving. Titration in vitro proved to be at least as sensitive as titration in rabbits. This conclusion is

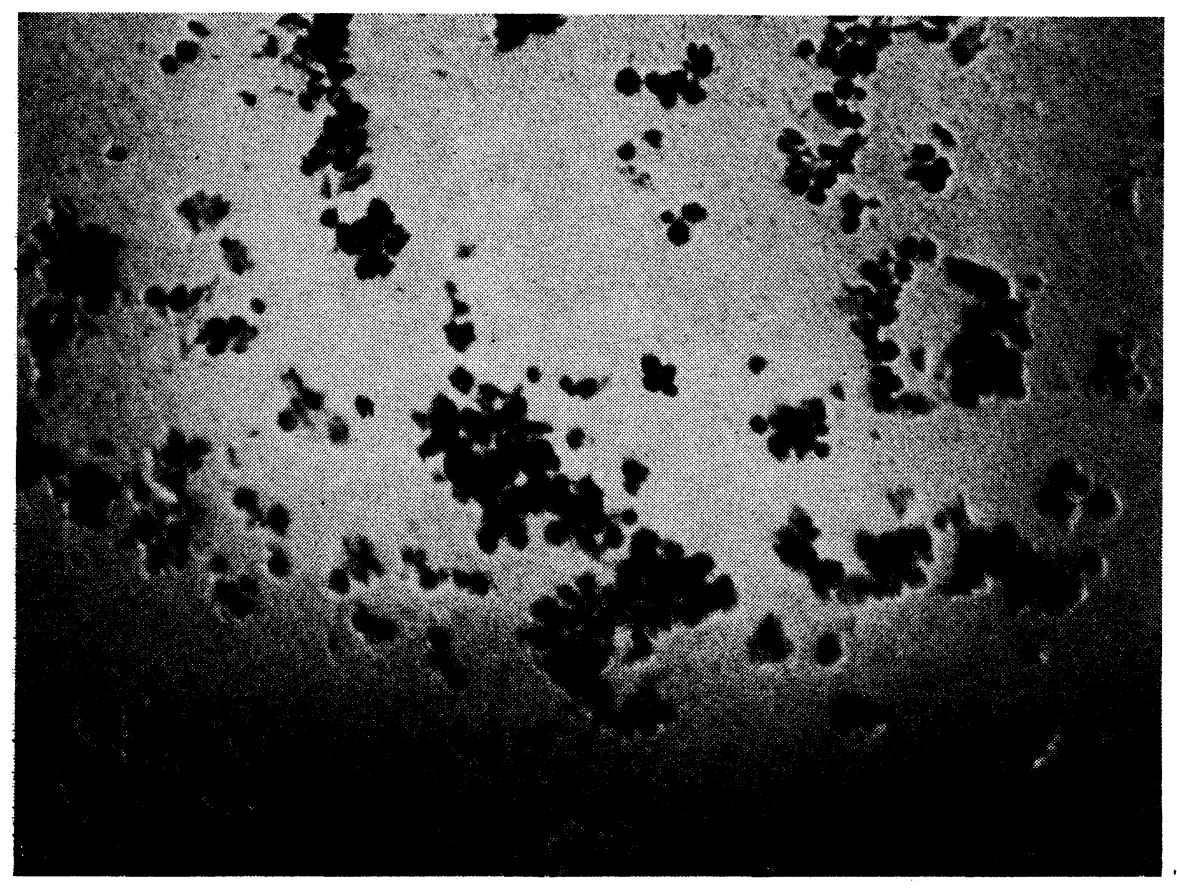

Fig. 5

Micromethod. Undiluted vaccine. Complete monolayer destruction. x 112. 


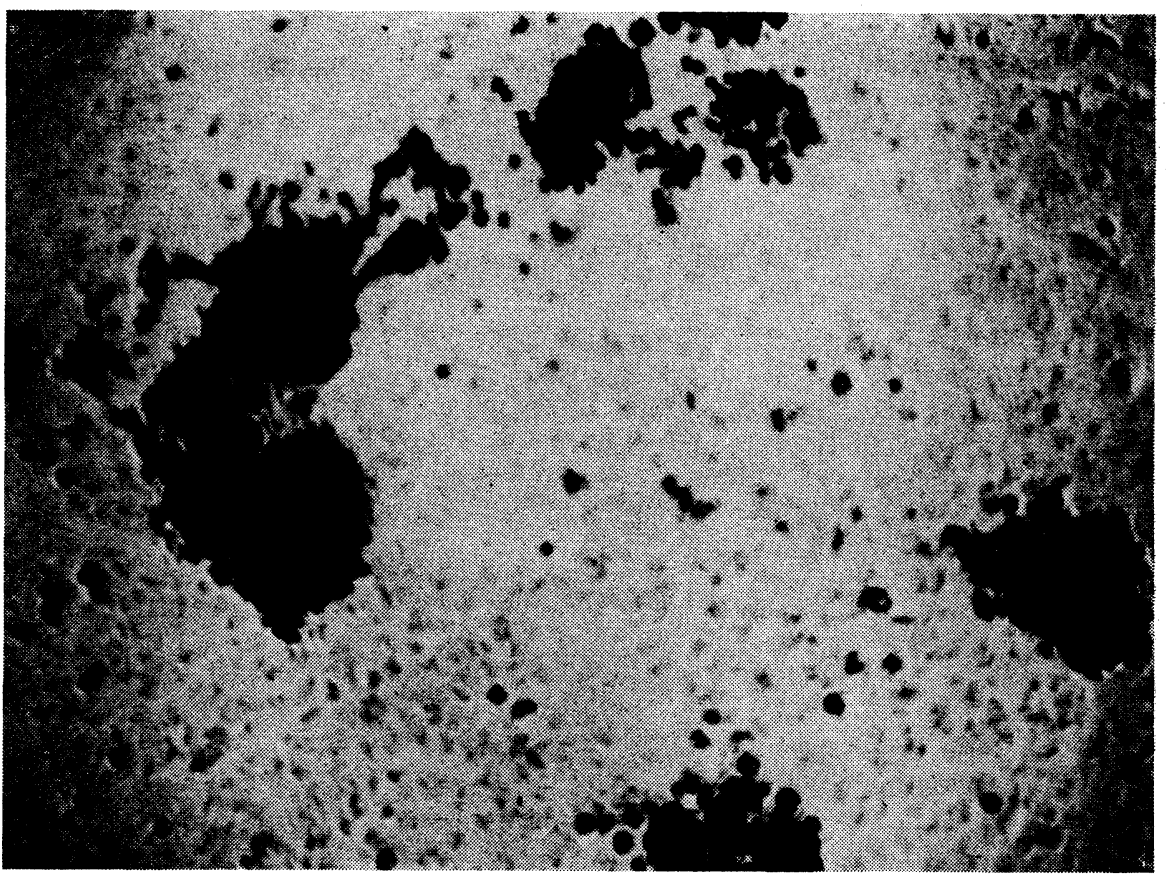

Fig. 6

Micromethod. Vaccine dilution $10^{-1}$. Characteristic hyperplastic foci of the monolayer. $\mathbf{x} 112$.

Table 1

Titers of the Shope fibroma virus in $\log 1 D_{50} / 1 \mathrm{~cm}^{3}$ after titration in rabbits and in vitro

\begin{tabular}{|c|c|c|c|}
\hline \multirow{2}{*}{$\begin{array}{c}\text { Sample } \\
\text { No. }\end{array}$} & Titration in rabbits & \multicolumn{2}{|c|}{ Titration in vitro } \\
\cline { 3 - 4 } & & test tube method & micromethod \\
\hline 1 & -3.8 & $-3,9$ & $\mathbf{N}$ \\
3 & -3.1 & -4.3 & $\mathbf{N}$ \\
4 & -3.7 & -3.8 & $\mathbf{N}$ \\
5 & -4.0 & -3.9 & -5.4 \\
6 & -4.9 & $\mathbf{N}$ & $-4,8$ \\
7 & -4.1 & $\mathbf{N}$ & -5.0 \\
8 & -4.1 & $\mathbf{N}$ & -5.3 \\
9 & -4.8 & $\mathbf{N}$ & -4.7 \\
10 & -3.4 & $\mathbf{N}$ & -5.0 \\
11 & -4.6 & $\mathbf{N}$ & -4.8 \\
12 & -4.0 & -4.6 & $\mathbf{N}$ \\
13 & -4.0 & -3.6 & $\mathbf{N}$ \\
14 & -4.0 & -3.6 & $\mathbf{N}$ \\
15 & -4.9 & -3.5 & $\mathbf{N}$ \\
16 & -4.2 & -3.5 & -3.8 \\
17 & -4.1 & -4.0 & -4.5 \\
18 & -4.1 & -4.0 & \\
19 & -4.1 & & \\
\hline
\end{tabular}

$\mathrm{N}=$ not done 
in good agreement with the data of Padgett et al. (1962), Verna and Eylar (1962), Jacquemont et al. (1972).

The different results obtained by the three titration methods as given in Table 1 can, in part be due to recalculation per $1 \mathrm{~cm}^{3}$. With the sample 14 also fairly non-homogenic suspension prepared from the SF virus propagated in rabbit skin for vaccine preparation may play a role. This view is also supported by the fact that with the remaining titrations where SFV propagated in cell cultures was employed, the results obtained by titration in vitro in majority of cases corresponded well with those obtained by titration in rabbits, with titres in vitro somewhat higher.

On basis of the present results it can be stated that the proposed procedure of vaccination virus titration in vitro can be used at each phase of the vaccine production including the final product control. Titration in vitro makes possible a very good vaccine standardization. Replacement of virus titration in rabbits by titration in vitro provides standard results and reduces costs of animal keeping. Titration in vitro can also be employed to test the vaccines incorrectly handled and stored.

\section{Titrace viru Shopeho fibromu in vitro}

K titraci viru Shopeho fibromu pomnožovaného na buněčné linii RK 13 je možno kromě králíků použít i buněčné kultury linie RK 13. Titrací in vitro, at již ve zkumavkách nebo mikrometodou na panelech, je možno nahradit dosavadní titraci na králících. Pro jednoduchost a malou pracovní náročnost je vhodnější mikrometoda. Titrací in vitro je možno ověřovat jednotlivé fáze výroby vakcíny, což je významné nejenom $z$ hlediska standardizace vakcíny, ale i z hlediska ekonomického.

\section{Титрование фибромы IIlоупа в пробирке}

Для титрования вируса фибромы Шоупа, размноженного на клетсчной линии РК 13 можно помимо кроликов исіользовать также клеточные культуры линии РК 13. Титрованием in vitro - в пробирке или микрометодом на панелях - можно заменить существующее до сих пор титрование на кроликах. Более выгодным является микрометод из-за присущей ему простоты приема. Титрованием in vitro можно проверять отдельные фазы производства вакцины; это, следовательно, играет важнуг роль не только с точки зрения стандартизации вакцины, но и с экономических аспектов.

\section{References}

CROUCH, N. A.: Replication of vesicular stomatitis virus facilitated in nonpermissive cells by early functions of Shope fibroma virus (40026). Proc. Soc. exp. Biol. Med., 157, 1978: 225.

CUPERA, Z.: Vakcína proti myxomatóze králikủ - účinnost a délka exspirace. Imunoprofylaxia, Bratislava, 2, 1969: 15.

HINZE, H. C. - WALKER, D. L.: Response of cultured rabbit cells to infection with the Shope fibroma virus. I. Proliferation and morphological alteration of the infected cells. J. Bact., 88, 1964: 1185.

HINZE, H. C. - WALKER, D. L.: Comparison of cytocidal and noncytocidal strains of Shope rabbit fibroma virus. J. Virol., 7, 1971: 577. 
JACQUEMONT, B. - OGIER, G. - LEFTHERIOTIS, E. - CHARDONNET, Y.: Étude de quelques propriétés biologiques du virus du fibrome de Shope: titrage et production du virus ,,in vivo" et , in vitro“. Annls Inst. Pasteur, 122, 1972: 489.

JERÁBEK, J.: Applicability of Shope fibroma virus replicated in cell cultures for immunoprophylaxis of rabbit myxomatosis. Acta vet. Brno, 49, 1980: 259-267.

KASZA, L.: Isolation and characterization of a rabbit fibroma virus from a naturally occurring tumor. Am. J. vet. Res., 35, 1974: 87.

MÁDR, V. - MACURA, B. - PETLACH, J.: Vakcína proti myxomatóze králíků z viru infekčního fibromu. Imunoprofylaxia, Bratislava, 2, 1967: 90.

MÁDR, V.: Vývoj vakcíny proti myxomatóze králíkủ. Project report. Ivanovice na Hané, Bioveta, 1971 .

PADGETT, B. L. - MOORE, M. S. - WALKER, D. L.: Plaque assays for myxoma and fibroma viruses and differentiation of the viruses by plaque form. Virology, 17, 1962: 462.

REED, L. J. - MUENCH, H.: A simple method of estimating fifty per cent endpoints. Am. J. Hyg., 27, 1938: 493.

VERNA, J. E. - EYLAR, O. R.: Rabbit fibroma virus plaque assay and in vitro studies. Virology, 18, 1962: 266.

WOODROOFE, G. M. - FENNER, F.: Viruses of the myxoma-fibroma subgroup of the poxviruses. 1. Plaque production in cultured cells, plaque-reduction tests, and cross-protection tests in rabbits. Austr. J. exp. Biol. med. Sci., 43, 1965: 123.

ZERBINI, M. - GUARDA, M. A. - PORTOLANI, M.: Intranuclear inclusions in Shope fibroma virus infected cells. Boll. Ist. Sieroter. Milanese, 54, 1975: 287. 